\section{Farmers' Perceptions, Production and Productivity Constraints, Preferences, and Breeding Priorities of Sweetpotato in Rwanda}

\author{
Rukundo Placide', Hussein Shimelis, and Mark Laing \\ African Centre for Crop Improvement, University of KwaZulu-Natal, Private \\ Bag X01, Scottsville 3209, Pietermaritzburg, South Africa
}

\section{Daphrose Gahakwa \\ Rwanda Agriculture Board (RAB), P.O. Box 5016, Kigali-Rwanda}

\begin{abstract}
Additional index words. breeding priorities, farmers' preferences, production constraints, sweetpotato
\end{abstract}

\begin{abstract}
The role of farmers and their production constraints and preferences are important for sweetpotato breeding and adoption of cultivars and agronomic production packages. The objective of this study was to assess farmers' perception, production constraints, preferences, and breeding priorities of sweetpotato in selected agro-ecologies of Rwanda. A total of 495 farmers were surveyed in 2013 in eight representative districts: Bugesera and Kayonza in the Eastern Province, Gakenke and Rulindo in the Northern Province, and Gisagara, Huye, and Muhanga in the Southern Province. Data were collected through a participatory rural appraisal (PRA) methodology using a semistructured questionnaire and focus group discussions. Pairwise comparison of 16 food crops allocated sweetpotato as one of the five important food crops for food security and income generation. Drought stress, unavailability of improved cultivars and planting material, and pest and disease damage were perceived to be the five main constraints limiting sweetpotato production, contributing to $17.3 \%, 15.0 \%, 12.9 \%, 11.7 \%$, and $11.5 \%$, respectively. The most important sweetpotato cultivar traits had high yield, early maturity, drought tolerance, disease and pest tolerance, and good culinary taste at $22.5 \%, 18.5 \%, 15.4 \%, 12.7 \%$, and $10.1 \%$, respectively. The characteristics of good storage roots identified by farmers included high dry matter content, good culinary taste, good shape, root size, and sweetness representing $27.4 \%, 18.8 \%, 16.1 \%, 11.6 \%$, and $9.4 \%$, respectively. Each agro-ecological zone has its own specific sweetpotato production constraints and farmers' preferences, necessitating targeted breeding of different sweetpotato cultivars for each agro-ecological zone for enhanced productivity and successful adoption of cultivars.
\end{abstract}

Globally the demand for quantity and quality food is fast increasing as a result of population growth, limited water and land, and overexploitation of available resources (Godfray et al., 2010; Tilman et al., 2001). Moreover, global climate change aggravates the biotic and abiotic stresses on food crops (Tester and Langridge, 2010). These environmental changes will negatively affect crop production and food security. Therefore, novel mitigation strategies are required to boost crop productivity and ensure food security. Improved and resilient crop cultivars and their production technologies are

Received for publication 24 Sept. 2014. Accepted for publication 18 Nov. 2014.

The Alliance for a Green Revolution in Africa (AGRA) is thanked for providing financial support of the study. The first author thanks the Rwanda Agricultural Board (RAB) for offering the study leave. Dr. Twabagire Barnabe is acknowledged for transport support during the conduct of this study. ${ }^{1}$ To whom reprint requests should be addressed; e-mail rukundoplacide@yahoo.fr.
There are varied preferences and needs by end users for crop cultivars. For instance, for industrial starch production, sweetpotato cultivars are required to have high dry matter content, whereas cultivars for human consumption should have other traits such as attractive skin and flesh color, good cooking quality, and high $\beta$-carotene, among others. Sweetpotato cultivars intended for animal feed should have high protein content (Lebot, 2009). Therefore, sweetpotato breeding should involve the needs of stakeholders in the developing of new cultivars and new agricultural technologies to meet their diverse requirements (Atlin et al., 2001; Rees et al., 2003).

Agricultural technologies developed through participatory research have a greater chance of adoption and diffusion by farmers because they are developed in response to local constraints and meet end users' needs and preferences (Ashby and Lilja, 2004). Various research approaches have been reported in participatory breeding of new crop cultivars, including consultative approaches, collaborative approaches, collegial approaches, and farmer experimentation (Ashby and Lilja, 2004). Advantages of farmer participatory research include: 1) codefinition of breeding objectives; 2) participatory evaluation of germplasm; 3) identification of breeding priorities; and 4) participatory selection of promising progenies (Ceccarelli and Grando, 2009). In one case, the incorporation of participatory approaches into conventional breeding programs reduced the time taken for cultivar development from 9 to 6 years (Lilja and Aw-Hasaan, 2003).

In sweetpotato breeding, farmers' knowledge and experience during preliminary on-farm and on-station evaluations may enable quick identification of promising genotypes (Abidin et al., 2005). Song (1998) reported that the end users' participation in the improvement of seed systems led to the efficient use of national genetic resources and promoted their production. In selection of high-yielding genotypes, Ceccarelli et al. (2009) observed that farmers have the same selection ability as breeders. Therefore, close collaboration between farmers and breeders is necessary to speed up the breeding process and to respond to appropriate needs of stakeholders.

Application of participatory research requires integrated skills (Ceccarelli et al., 2009). A careful choice of research goals, target environments, and selection of partners are critical steps of participatory research. It also demands a systematic understanding of different types of participatory research approaches to select the most appropriate tools (Ashby and Lilja, 2004) such as participatory rural appraisal, focus group discussions, participatory selection in segregating populations, and participatory cultivar testing and selection (Sperling et al., 2001).

Sweetpotato is an important food and feed crop in sub-Sahara Africa and ranks fourth after maize, bananas, and cassava (FAOSTAT, 2013). It yields considerably well in poor soils and tolerates extreme weather conditions unsuitable to other food crops such as maize and banana (Woolfe, 1992). Therefore, it has an important role in food security in many 
rural families of drought-affected environments (Bashaasha et al., 1995). Rwanda is the third in sweetpotato production in East Africa and the first in per-capita consumption of sweetpotato in Africa (Chassy et al., 2008). More than $95 \%$ of Rwandan farmers grow sweetpotato for household food security (Njeru et al., 2008). During the farming seasons many rural families rely on sweetpotato because of a shortage of other food security crops such as cassava, potato, banana, and maize (Gibson et al., 2004; Njeru et al., 2008). As a result of its high productivity per unit area and continuous availability, sweetpotato is an ideal food crop for Rwanda, the most densely populated (416 persons $/ \mathrm{km}^{2}$ ) country in Africa, with limited agricultural land (NISR, 2012). The crop requires less production inputs such as fertilizers and pesticides than other major crops (Woolfe, 1992). However, the average sweetpotato yield in Rwanda is low, $5.9 \mathrm{t} \cdot \mathrm{ha}^{-1}$ wet weight compared with yields of 22.8 and $21.7 \mathrm{t} \cdot \mathrm{ha}^{-1}$ reported in the United States and Japan, respectively (FAOSTAT, 2013). This requires targeted participatory sweetpotato breeding to develop improved and highyielding cultivars, and their production packages, according to the needs of the growers in the country. Therefore, the objective of this study was to assess farmers' perception, production and productivity constraints, preferences, and breeding priorities of sweetpotato in selected agro-ecologies of Rwanda. Results of the study may assist in the breeding and sustainable production of sweetpotato in Rwanda and countries with similar agro-ecologies.

\section{Materials and Methods}

Description of the study areas. The study was carried out in 2013 in Bugesera and
Kayonza districts of Eastern Province, Gakenke and Rulindo districts of Northern Province, and Gisagara, Huye, and Muhanga districts of the Southern Province of Rwanda (Fig. 1). These districts were selected because of the importance of sweetpotato production in their food production (Ndamage et al., 1992). Agriculture is the main economic activity of the selected districts, employing more than $90 \%$ of the population. In these districts farmers grow many food crops including beans, sorghum, sweetpotato, bananas, and maize (NISR, 2010). The Rwanda Agricultural Board (RAB) has promoted cultivation of sweetpotato in these areas to produce raw material for the Urwibutso Enterprise, which was established for the industrial production of sweetpotato biscuits, cakes, bread, and juice (Rwakabuba, 2012). In Gisagara, Huye, and Muhanga districts, a range of food crops is grown, including sweetpotato, which is the main food crop supplied to provincial cities (Kayitare, 2006).

Sampling method. A multistage sampling was used for the study. Two sectors in each district were sampled. In each sector two villages were subsampled and six to eight farmers were randomly selected in each village. This provided a total of 168 farmers for semistructured interviews. A further 14 focus groups were established with 327 farmers for focus group discussions. Each focus group had between 20 and 26 farmers selected by local leaders and agronomists in each sector. Participants for group discussions were selected to represent the spectrum of individual farmers and farmers from various cooperative associations of the villages, taking into account gender balance.

Data collection. Data were collected using established participatory rural appraisal tools. A semistructured questionnaire was used in the survey to collect information related to the importance of sweetpotato, constraints affecting sweetpotato production, characteristics of good cultivars, and good storage roots, farmers' agronomic practices, and sources of planting materials.

Different PRA approaches were applied to identify periods of sweetpotato production, food availability across the year, the importance of sweetpotato in food security and income generation, farmers' preferences, the most serious constraints affecting sweetpotato, and the role of gender in sweetpotato production. Seasonal calendar analyses were used to identify planting and harvesting periods of sweetpotato, the periods of limited availability and overproduction, and the fluctuation of sweetpotato prices on market. Pairwise and ranking matrices were used to identify the importance of sweetpotato as a food security crop and as an income-generation crop. A matrix scoring method was used following Ceccarelli's approach (2012) to rank farmers' and consumers' preferences, constraints of sweetpotato production, characteristics of good storage roots and cultivars of sweetpotato, and the role of gender in sweetpotato production in Rwanda. Participants listed the best criteria and data were organized on flipcharts followed by ranking using a fixed number of votes. After votes were given by participants, percentage values of each parameter were calculated.

Data analysis. Data collected were analyzed using SPSS (PASW statistics 18.0) computer package (SPSS, 2006), Genstat 15th edition (Payne et al., 2011), and Microsoft Excel (Windows Office 2012; Microsoft Inc., Redmond, WA). Variables were subjected to descriptive statistics, one-sample $t$ test, and crosstabulation and $\chi^{2}$ analyses.

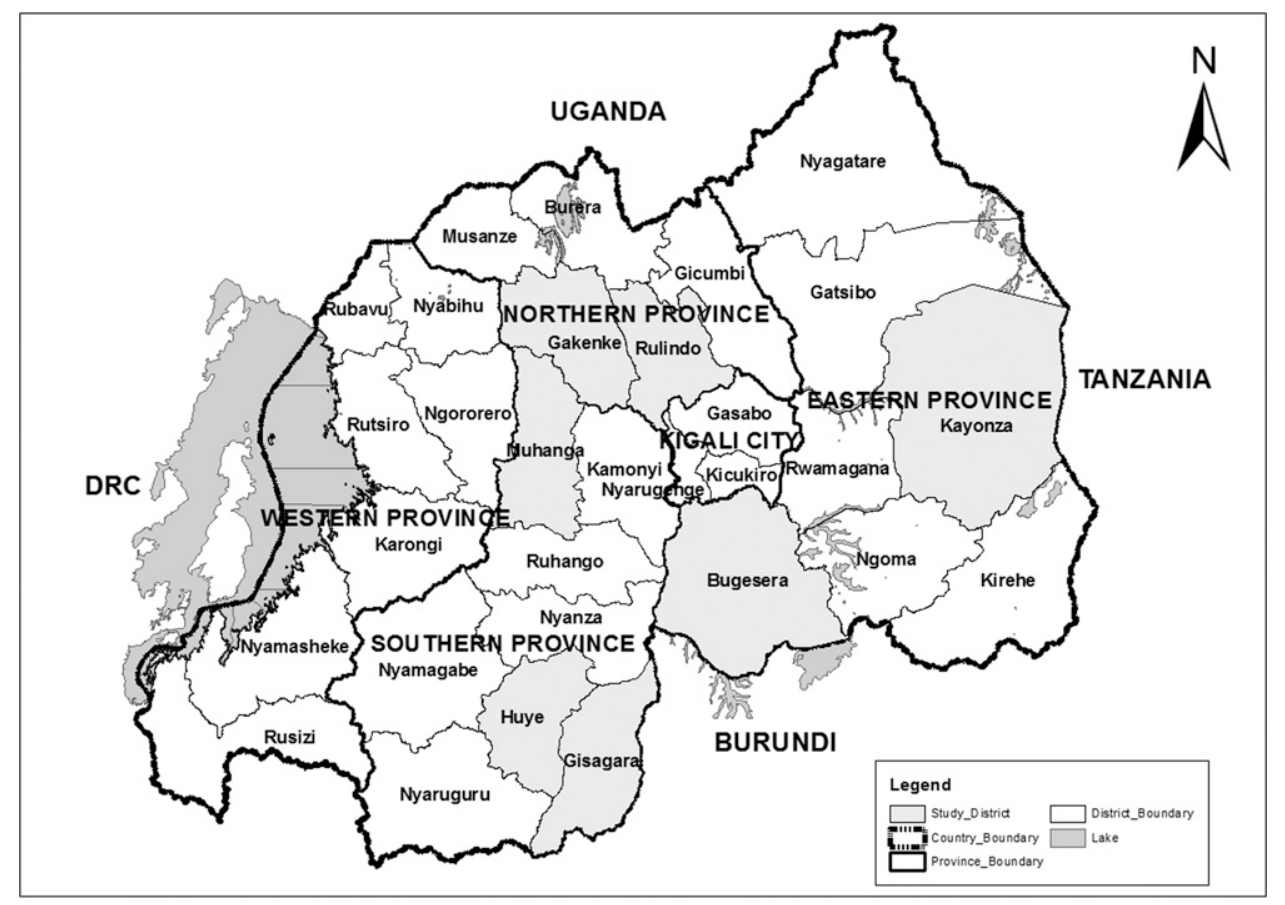

Fig. 1. A map of Rwanda showing the districts where the survey was conducted. 


\section{Results}

\section{Demographic description of the study areas}

The most important variables and descriptions of farmers chosen for the study are presented in Table 1. The number of female respondents was higher than males. Females represented $58.4 \%$, whereas males were at $41.6 \%$. The total number of interviewed farmers during the survey was 168 , whereas 327 farmers were available for group discussions.

In this survey, $67.3 \%$ of the farmers had finished primary school, $4.2 \%$ had completed post-primary school, $1.4 \%$ had attended secondary school, and $26.9 \%$ were illiterate (Table 1). Training in agricultural practices was limited with only $28.5 \%$ of the interviewed farmers having been trained in some agricultural practices by various organizations such as World Vision and Catholic Relief Services, the Food Agricultural
Organisation of the United Nations, and national public agricultural institutions such as the Institut des Siences Agronomique du Rwanda, the Rwanda Agricultural Development Authority, and the RAB. Most farmers' training had focused on use of agricultural inputs, soil conservation, and agronomic crop management.

\section{Farmers' perception and sweetpotato production}

Importance of sweetpotato. The results from a pairwise comparison of the 16 food crops grown by farmers (banana, bean, cassava, cocoyam, fruit, Irish potato, maize, groundnut, dry peas, rice, sorghum, soybean, sunflower, sweetpotato, vegetables, and yam) revealed that the positions of sweetpotato in terms of food security and income generation varied from one district to another (Tables 2 and 3). In Bugesera district, sweetpotato ranked fourth as a food security crop after banana, bean, and cassava and ranked fifth in income generation. In Kayonza district, sweetpotato ranked fifth after bean, cassava, banana, and rice for food security and ranked 13th in income generation. In Gakenke district, sweetpotato ranked fourth as a food security crop after banana, bean, and cassava and third in income generation. In Rulindo district, it was the fourth food security crop and the fifth in income generation. In Gisagara district, sweetpotato was the third food security crop after banana and cassava and the fifth in income generation. In Huye district, it ranked third for food security after cassava and bean and the sixth in income generation. In Muhanga district, sweetpotato was the fourth after bean, cassava, and banana as a food security crop and the sixth in income generation. In all districts of the study, cassava, banana, and sweetpotato were among the first five food crops, whereas banana was the only crop ranked among the first five crops in income generation.

Table 1. Description of sampled farmers from three provinces and seven districts of Rwanda in 2013.

\begin{tabular}{|c|c|c|c|c|c|c|c|c|c|c|c|c|c|c|c|}
\hline \multirow[b]{2}{*}{ Variable } & \multicolumn{2}{|c|}{ Eastern Province } & \multicolumn{2}{|c|}{ Northern Province } & \multicolumn{3}{|c|}{ Southern Province } & \multirow[b]{2}{*}{ Total } & \multirow[b]{2}{*}{ Percent } & \multirow[b]{2}{*}{ Variance } & \multirow[b]{2}{*}{ SD } & \multirow{2}{*}{$\mathrm{SE}$} & \multirow{2}{*}{$\begin{array}{c}t \text { test } \\
\text { statistic }\end{array}$} & \multirow[b]{2}{*}{ CI $(95 \%)$} & \multirow[b]{2}{*}{ Probability* } \\
\hline & Bugesera & Kayonza & Gakenke & Rulindo & Gisagara & Huye & Muhanga & & & & & & & & \\
\hline Female & 37 & 31 & 49 & 56 & 39 & 36 & 41 & 289 & 58.4 & 72.2 & 8.5 & 3.2 & 12.9 & $(33.43-49.15)$ & $<0.001$ \\
\hline$<25$ & 13 & 6 & 7 & 12 & 10 & 0 & 0 & 47 & 9.5 & 28 & 5.3 & 2 & 3.4 & $(1.85-11.65)$ & 0.015 \\
\hline $26-40$ & 27 & 11 & 25 & 27 & 19 & 21 & 34 & 164 & 33.1 & 52.6 & 7.3 & 2.7 & 8.5 & $(16.68-30.10)$ & $<0.001$ \\
\hline$>40$ & 23 & 33 & 53 & 51 & 48 & 41 & 34 & 284 & 57.4 & 119.7 & 10.9 & 4.1 & 9.8 & $(30.45-50.69)$ & $<0.001$ \\
\hline Primary & 56 & 2 & 50 & 78 & 67 & 28 & 26 & 333 & 67.3 & 434.7 & 20.9 & 7.9 & 6.1 & (28.48-67.04) & $<0.001$ \\
\hline Postprimary & 3 & 0 & 4 & 0 & 0 & 7 & 7 & 21 & 4.2 & 9.9 & 3.1 & 1.2 & 2.6 & $(0.13-5.94)$ & 0.043 \\
\hline Secondary & 0 & 0 & 0 & 0 & 0 & 7 & 0 & 7 & 1.4 & 6.8 & 2.6 & 1 & 1 & $(-1.42$ to 3.39$)$ & 0.356 \\
\hline \multicolumn{16}{|l|}{ Family size } \\
\hline$<5$ & 27 & 28 & 39 & 47 & 48 & 48 & 34 & 271 & 54.7 & 89.6 & 9.5 & 3.6 & 10.8 & $(29.90-47.40)$ & $<0.001$ \\
\hline $6-10$ & 36 & 22 & 46 & 43 & 29 & 14 & 34 & 224 & 45.2 & 130.1 & 11.4 & 4.3 & 7.4 & $(21.51-42.61)$ & $<0.001$ \\
\hline \multicolumn{16}{|c|}{ Belongs to association } \\
\hline
\end{tabular}

*Probability values based on one-sample $t$ test.

$\mathrm{CI}=$ confidence interval.

Table 2. Score (\%) of main food crops in terms of food security following a pairwise comparison of farmers $(\mathrm{N}=327)$ of three provinces and seven districts of Rwanda.

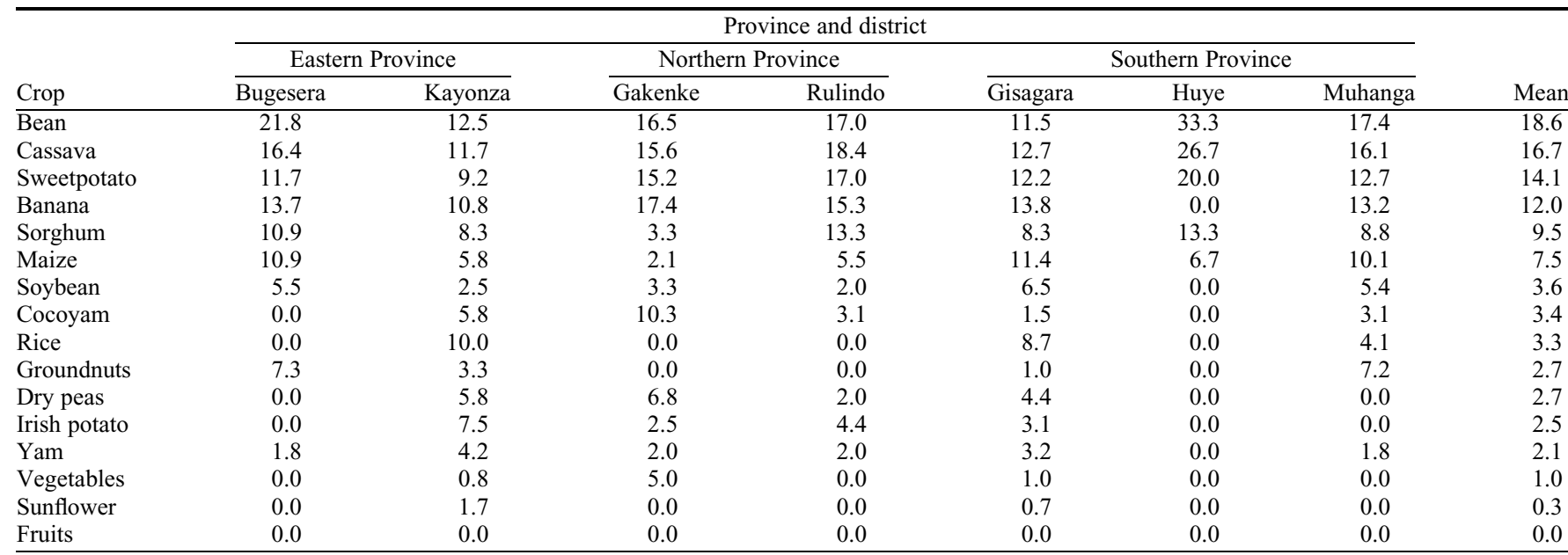


Constraints of sweetpotato production. The main constraints of sweetpotato production and their relative importance as reported by farmers during group discussions are presented in Table 4. In Bugesera district, drought, a shortage of planting materials (vines), and diseases were the three top constraints reported by farmers. Shortage of improved cultivars, drought, and pests were the leading constraints of sweetpotato production in Kayonza district. In Gakenke district, drought, diseases, and pests were considered the main three sweetpotato production constraints. In Rulindo district, drought, diseases, and shortage of vines were regarded as the most important constraints of sweetpotato production. In Gisagara district, farmers reported that drought, pests, and shortage of improved cultivars were the main production constraints. In Huye district, pests, drought, and shortage of vines were identified as the most important constraints of sweetpotato production. In Muhanga district, farmers prioritized drought, pests, and shortage of vines as the three main constraints of sweetpotato production. Overall, in the surveyed districts, drought stress, shortage of improved cultivars and planting material, and pest and disease damages were the five main constraints of sweetpotato production reported by farmers. These constraints represented at $17.3 \%, 15.0 \%$, $12.9 \%, 11.7 \%$, and $11.5 \%$, respectively.
Farmers' preferences for sweetpotato cultivars and storage root traits. Various characteristics of a good sweetpotato cultivar and a good storage root were identified by respondent farmers (Table 5). The most farmer-preferred traits of a sweetpotato cultivar were high yield, early maturity, drought resistance, disease and pest resistance, good culinary taste, big storage roots, broad adaptability, good appearance of the storage roots, and high vine yield (Table 5). These were reflected by the votes for high yield, early maturity, drought tolerance, disease and pest tolerance, and good culinary taste being $22.5 \%, 18.3 \%, 15.1 \%, 12.3 \%$, and $10.1 \%$, respectively.

Farmers reported various characteristics of good storage roots such as skin color (white, cream, yellow, orange, brown, pink, red, or purple), high dry matter content, low fiber content, good taste, big size, varied shapes (round elliptic, elliptic, ovate, obovate, oblong, long oblong, long elliptic, or long irregular), and sweetness (Table 5). However, preferences varied between farmers. The main five characteristics of good storage roots identified by farmers were high dry matter content, good culinary taste, good shape, storage root size, and storage root flesh color with votes of $24.2 \%, 18.4 \%, 14.6 \%, 12.9 \%$, and $9.5 \%$, respectively. Farmers grow cultivars with various flesh colors (white, cream, orange, yellow). The value of orange-fleshed sweetpotato is known by farmers but cultivars with white flesh color dominate other cultivars.

Sweetpotato farming practices. Farmers grew sweetpotato on ridges $(48.1 \%)$, flat ground $(37.5 \%)$, or mounds $(14.4 \%)$. Approximately $40.5 \%$ of farmers grew sweetpotato in an intercropping system with another crop. Sweetpotato is mainly intercropped with cassava, bean, and maize. Farmers prepare cuttings for large-scale planting from their own fields or collect vines from fields of neighbors. Production inputs such as fertilizers and pesticides are not commonly used by most of interviewed farmers for sweetpotato cultivation in Rwanda.

Seasonal calendar of sweetpotato production and market. The price of sweetpotato varied among districts and over months (Table 6). The price of $1 \mathrm{~kg}$ of sweetpotato reported by farmers ranged from 40 to 160 Rwandese francs (Rwf) (\$1 U.S. $=680$ Rwf) at Bugesera, 50 to 180 at Kayonza, 60 to 170 at Gakenke, 70 to 180 at Rulindo, 70 to 200 at Gisagara, 70 to 200 at Huye, and 70 to 200 at Muhanga. High market prices were reported in November, December, and January when there was a slack, whereas low prices were noted in the months of September, October, March, and April during a glut.

Farmers indicated that the availability of sweetpotato is usually limited during the months of November, December, January,

Table 3. Score $(\%)$ of main food crops in terms of income generation after a pairwise comparison of farmers $(\mathrm{N}=327)$ of three provinces and seven districts of Rwanda.

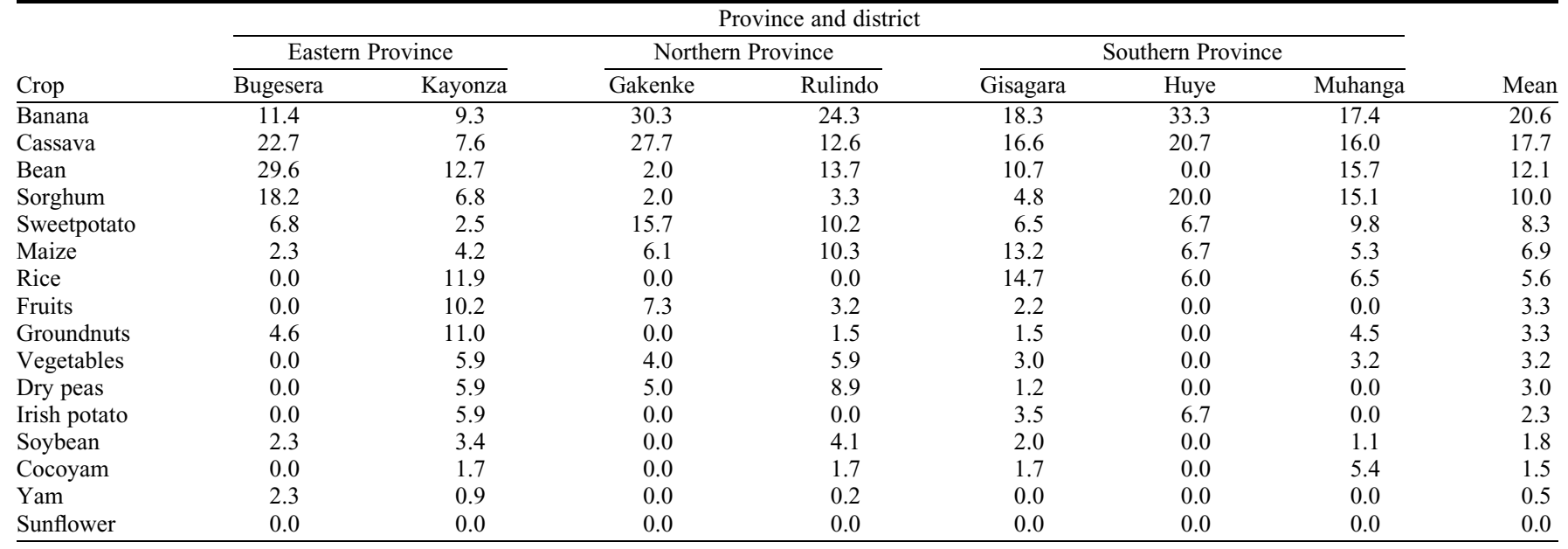

Table 4. Constraints of sweetpotato production and their relative importance (\%) of three provinces and seven districts of Rwanda.

\begin{tabular}{|c|c|c|c|c|c|c|c|c|}
\hline \multirow[b]{3}{*}{ Constraint } & \multicolumn{7}{|c|}{ Province and district } & \multirow[b]{3}{*}{ Mean } \\
\hline & \multicolumn{2}{|c|}{ Eastern Province } & \multicolumn{2}{|c|}{ Northern Province } & \multicolumn{3}{|c|}{ Southern Province } & \\
\hline & Bugesera & $\overline{\text { Kayonza }}$ & Gakenke & Rulindo & Gisagara & Huye & $\overline{\text { Muhanga }}$ & \\
\hline Shortage of improved cultivar & 11.0 & 19.8 & 10.1 & 6.0 & 14.6 & 10.0 & 10.1 & 11.7 \\
\hline Shortage of land & 3.0 & 11.5 & 10.8 & 3.0 & 12.1 & 9.8 & 13.3 & 9.1 \\
\hline Drought & 15.7 & 19.1 & 17.2 & 15.7 & 16.3 & 17.2 & 20.1 & 17.3 \\
\hline Diseases & 13.9 & 11.5 & 15.0 & 14.9 & 12.5 & 12.0 & 10.8 & 12.9 \\
\hline Pests & 12.4 & 16.3 & 15.1 & 12.4 & 15.6 & 18.1 & 15.3 & 15.0 \\
\hline Training & 9.0 & 2.0 & 5.3 & 8.5 & 5.4 & 5.3 & 2.0 & 5.4 \\
\hline Shortage of planting material & 14.8 & 8.1 & 9.2 & 14.8 & 7.4 & 11.2 & 15.3 & 11.5 \\
\hline Low market demand & 9.2 & 7.0 & 3.1 & 5.2 & 4.4 & 3.1 & 4.0 & 5.1 \\
\hline
\end{tabular}


and February. These periods correspond with the highest market prices for sweetpotato (Tables 6 and 7). Overproduction and a market glut of the crop occur from April to August (Table 7). Other food crops produced during the months of sweetpotato overproduction included bean, rice, sweetpotato, maize, Irish potato, cocoyam, pumpkin, banana, and sorghum.

Gender and sweetpotato production. Activities of sweetpotato production are carried out by male and female farmers. However, female farmers contributed more than males in the overall sweetpotato production in Rwanda (Table 8). Farmers reported that the management of income derived from the sale of production depends on the market size. In case of big markets, for example, during the sale of bulk quantity of sweetpotato such as to a school or factory, income is managed by males in $100 \%$ of cases. However, in cases of small markets, for example, selling few baskets of sweetpotato in a local market, the sales are managed by females in $70 \%$ of cases.

\section{Discussion}

Use of sweetpotato for food security and income generation. Food insecurity is a major problem in many nations as a result of biotic and abiotic constraints. According to Tshuma (2012), food security is achieved at various levels such as individual, family, national, regional, and global levels. Food security encompasses physical and economic access to sufficient quality and quantity food for an active and healthy life. Sweetpotato has been reported to be an important crop in the food security and economy of poor households in the marginal agro-ecological zones (Bashaasha et al., 1995; Githunguri et al., 2006). Bashaasha et al. (1995) observed that farmers' sweetpotato plots contain many cultivars, which have various attributes such as maturity periods. Variation in maturity periods contributes to the continuous supply of food over the year. In Rwanda, the contribution of sweetpotato to family food security and income generation varied from one district to another (Tables 2 and 3). However, in all the study areas, sweetpotato was ranked among the top five major food crops.

Constraints to sweetpotato production. In the assessment of priorities for sweetpotato research in developing countries, Fuglie (2007) found common production constraints in almost all the major sweetpotato-producing areas. Some constraints were specific to certain regions. Viral diseases, shortage of post-harvest

Table 5. Preferred characteristics of a good cultivar and storage root of sweetpotato and their relative score (\%) by growers in Bugesera, Kayonza Gakenke, Rulindo Gisagara, Huye, and Muhanga districts of Rwanda.

\begin{tabular}{|c|c|c|c|c|c|c|c|c|}
\hline \multirow{3}{*}{ Cultivar } & \multicolumn{2}{|c|}{ Eastern Province } & \multicolumn{2}{|c|}{ Northern Province } & \multicolumn{3}{|c|}{ Southern Province } & \multirow[b]{3}{*}{ Score $(\%)$} \\
\hline & Bugesera & Kayonza & Gakenke & Rulindo & Gisagara & Huye & Muhanga & \\
\hline & \multicolumn{4}{|c|}{ Cultivar preferences } & & & & \\
\hline High yield & 19.8 & 24.8 & 25.3 & 19.4 & 23.3 & 22.6 & 22.3 & 22.5 \\
\hline Earlier maturity & 17.7 & 16.7 & 17.5 & 18.7 & 21.2 & 17.2 & 19.4 & 18.3 \\
\hline Drought resistance & 16.0 & 15.1 & 16.8 & 13.0 & 13.6 & 15.5 & 15.6 & 15.1 \\
\hline Disease and pest tolerance & 13.2 & 13.0 & 12.4 & 11.2 & 11.1 & 12.0 & 13.1 & 12.3 \\
\hline Good culinary taste & 9.3 & 12.5 & 12.0 & 10.3 & 9.2 & 9.3 & 8.2 & 10.1 \\
\hline Big storage root & 9.2 & 11.2 & 1.6 & 10.2 & 9.7 & 8.9 & 9.9 & 8.7 \\
\hline Broad adaptation & 3.8 & 1.8 & 4.5 & 4.8 & 3.8 & 4.1 & 3.8 & 3.8 \\
\hline Good appearance of storage root & 3.1 & 3.1 & 1.8 & 4.1 & 2.5 & 3.5 & 3.1 & 3.0 \\
\hline High vine yield & 3.2 & 1.2 & 4.1 & 4.2 & 3.1 & 3.6 & 2.7 & 3.2 \\
\hline \multirow[t]{2}{*}{ All other traits } & 4.7 & 0.6 & 4.1 & 4.1 & 2.6 & 3.4 & 2.0 & 3.1 \\
\hline & \multicolumn{4}{|c|}{ Storage root preferences } & & & & Votes $(\%)$ \\
\hline High dry matter content & 24.3 & 22.8 & 29.3 & 23.4 & 21.3 & 28.6 & 19.8 & 24.2 \\
\hline Good culinary taste & 17.4 & 18.7 & 17.5 & 22.7 & 20.2 & 14.3 & 17.7 & 18.4 \\
\hline Good shape & 16.6 & 15.1 & 14.7 & 13.0 & 13.6 & 13.5 & 16.0 & 14.6 \\
\hline Storage root size & 12.1 & 13.0 & 12.4 & 11.2 & 16.1 & 11.9 & 13.2 & 12.9 \\
\hline Storage root fresh color & 9.9 & 11.2 & 2.6 & 12.2 & 11.7 & 9.9 & 9.2 & 9.5 \\
\hline Sweetness & 8.2 & 12.5 & 9.2 & 3.0 & 7.2 & 8.2 & 9.3 & 8.2 \\
\hline No sweet & 3.8 & 1.8 & 4.4 & 2.0 & 3.8 & 2.1 & 3.8 & 3.1 \\
\hline Less fibers & 3.1 & 3.1 & 4.6 & 4.8 & 3.5 & 4.5 & 3.1 & 3.8 \\
\hline Skin color & 3.7 & 0.2 & 3.3 & 6.2 & 2.1 & 3.4 & 3.2 & 3.2 \\
\hline Others & 1.0 & 1.6 & 2.0 & 1.5 & 0.6 & 3.6 & 4.7 & 2.1 \\
\hline
\end{tabular}

Table 6. Market price variation of sweetpotato (Rwf $/ \mathrm{kg}$ ) in Bugesera, Kayonza Gakenke, Rulindo Gisagara, Huye, and Muhanga districts of Rwanda in 2013.

\begin{tabular}{|c|c|c|c|c|c|c|c|c|c|c|c|c|}
\hline \multirow[b]{2}{*}{ District } & \multicolumn{12}{|c|}{ Month } \\
\hline & January & February & March & April & May & June & July & August & September & October & November & December \\
\hline Kayonza & 180 & 130 & 90 & 90 & 110 & 130 & 130 & 120 & 50 & 110 & 180 & 180 \\
\hline Gisagara & 200 & 160 & 120 & 120 & 120 & 120 & 120 & 100 & 70 & 140 & 170 & 170 \\
\hline Huye & 200 & 170 & 100 & 100 & 120 & 140 & 140 & 130 & 70 & 120 & 200 & 200 \\
\hline Muhanga & 180 & 140 & 120 & 110 & 110 & 110 & 110 & 100 & 70 & 150 & 200 & 200 \\
\hline
\end{tabular}

Table 7. Availability and seasonal calendar of sweetpotato production in Rwanda.

\begin{tabular}{|c|c|c|c|c|c|c|c|c|c|c|c|c|}
\hline \multirow[b]{2}{*}{ Period } & \multicolumn{12}{|c|}{ Month } \\
\hline & January & February & March & April & May & June & July & August & September & October & November & December \\
\hline $\begin{array}{l}\text { Overproduction } \\
\text { Planting }\end{array}$ & $\mathrm{x}$ & $\mathrm{x}$ & $\mathrm{x}$ & $\begin{array}{l}\lambda \\
x\end{array}$ & $\boldsymbol{\lambda}$ & $\begin{array}{l}\mathrm{x} \\
\mathrm{x}\end{array}$ & $\begin{array}{l}\lambda \\
x\end{array}$ & $\lambda$ & & & $\mathrm{x}$ & $X$ \\
\hline
\end{tabular}

$\mathrm{X}=$ month of the period. 
Table 8. Sweetpotato production activities and role of gender of three provinces and seven districts of Rwanda.

\begin{tabular}{|c|c|c|c|c|c|c|}
\hline \multirow[b]{2}{*}{ Activity } & \multicolumn{2}{|c|}{ Eastern Province } & \multicolumn{2}{|c|}{ Northern Province } & \multicolumn{2}{|c|}{ Southern Province } \\
\hline & Male & Female & Male & Female & Male & Female \\
\hline Land preparation & 42.4 & 57.7 & 45.9 & 54.2 & 53.7 & 46.3 \\
\hline Fertilization & 44.0 & 56.1 & 45.6 & 54.4 & 34.2 & 65.8 \\
\hline $\begin{array}{l}\text { Preparation of } \\
\text { planting material }\end{array}$ & 5.1 & 95.0 & 27.3 & 72.8 & 23.0 & 77.0 \\
\hline Planting & 0.0 & 100.0 & 10.3 & 89.7 & 15.1 & 84.9 \\
\hline Weeding & 22.9 & 77.1 & 27.0 & 73.1 & 25.0 & 75.0 \\
\hline Harvesting & 19.8 & 80.2 & 13.4 & 86.6 & 17.8 & 82.2 \\
\hline Sorting & 5.5 & 94.6 & 10.9 & 89.2 & 9.8 & 90.2 \\
\hline Cleaning & 7.5 & 92.5 & 4.1 & 95.9 & 5.6 & 94.4 \\
\hline Selling & 16.9 & 83.2 & 17.9 & 82.1 & 16.8 & 83.2 \\
\hline Percentage (\%) & 18.2 & 81.8 & 22.5 & 77.6 & 22.3 & 77.7 \\
\hline
\end{tabular}

processing technologies, lack of clean planting materials, and improved cultivars with high and stable yield potential were the main constraints of sweetpotato production in almost all the major sweetpotato-producing regions. Sweetpotato weevils and butterflies were the main pests of sweetpotato, whereas drought stress was the most important abiotic stress in Uganda (Bashaasha et al., 1995; Muyinza et al., 2007). Kapinga and Carey (2003) reported that viral and Alternaria diseases, drought, shortage of planting materials, and low soil fertility were the main production constraints of sweetpotato in Rwanda. Unlike previous finings, the present study found types and intensity of sweetpotato production constraints differed across districts (Table 4). Drought stress, shortage of improved cultivars and planting material, and pest and disease damage were the five main constraints of sweetpotato production reported by farmers in Rwanda.

Attributes of good sweetpotato cultivars and storage roots. The selection of cultivars to be grown by farmers is tightly linked to farmers' preferences and cultivar characteristics. Different storage root characteristics such as storage root formation, root shape, surface defects, latex production, skin and fresh color, dry matter content, sugar content and culinary taste are positive attributes for farmers' choices of cultivars in Uganda (Gibson et al., 2008). High dry matter content, good shape, and culinary taste were the main characteristics of good storage roots in the present study. It was also observed that a good cultivar must have high yields, early maturity, and drought tolerance (Table 5). In another study, Laurie and Magoro (2008) in South Africa found that the most important traits used by farmers to select good sweetpotato cultivars were a sweet taste, dry texture, and good yield. Githunguri et al. (2006) observed that yield is the most important selection criterion of a good cultivar of sweetpotato in Kenya. Low fiber and high dry matter content and taste were the main characteristics influencing the choice of good storage root by Kenyan women farmers (Githunguri et al., 2006). In a participatory cultivar selection, characteristics such as high yield, early maturity, and large storage root were the main attributes of a good cultivar (Gibson et al., 2008). High dry matter content is the main characteristic for sweetpotato processors and consumers, whereas skin color and root shape are also important traits of preference for sweetpotato cultivars (Rees et al., 2003). These findings reveal that farmers' and end users' preferences are diverse. Therefore, there is a need for clear communication between breeders and stakeholders for the successful improvement of the crop with high levels of farmer adoption of new cultivars. (VAD) prevails in Rwanda, especially among women. In the country, $7 \%$ of mothers showed some form of night blindness during their last pregnancy. A 5\% VAD in a population is reported to be severe (Shaikh and Mahy, 2003). To tackle VAD, the government of Rwanda adopted a schedule of vitamin A supplements in the form of capsules to all children aged from 6 to 59 months. Also, a single dose of vitamin A supplement is being given to mothers 2 months after delivery. However, this practice is expensive and depends on positive perception by the population toward vitamin A supplementation. Contrastingly, Van Jaarsveld et al. (2005) found that daily consumption of $125 \mathrm{~g}$ of orange-fleshed sweetpotato improved the vitamin A needs of sweetpotato could play a significant role in circumventing VAD in developing countries as a cheap, alternative, and long-term food-based strategy. By virtue of its wide-area production and daily consumption by a large group of the population, promotion of the orange-fleshed sweetpotato cultivars could have a substantial effect to combat VAD in Rwanda. Therefore, sweetpotato breeding programs in the country should consider $\beta$-carotene content as one of the important traits to develop high-yielding and vitamin A-enriched cultivars.

Agronomic management of sweetpotato. In Uganda, sweetpotato is cultivated on small plots, mainly in upland areas, during the rainy season and wetland during the dry season for vine maintenance (Bashaasha et al., 1995). However, in Rwanda, the wetlands are dedicated to cereal crop production, mainly rice and maize, with none of these lands used for sweetpotato production.

Sweetpotato is grown on ridges, mounds, or flat ground in Rwanda. The size of ridges and mounds varies and the number of vines per mound and ridge depends on vine sizes.
A high level of vitamin A deficiency children in South Africa. This suggests that
Bashaasha et al. (1995) reported that in highland areas, ridges are used to control soil erosion. In Rwanda, however, the effects of ridging, mounds, or flat ground on yield of sweetpotato are not well documented. Therefore, a detailed study is needed to develop recommendations for the proper method of planting and land preparation for all soil conditions and geographical aspects and gradients of lands.

This study showed that a high proportion $(59.5 \%)$ of sweetpotato is grown under monoculture, but that it is sometimes intercropped with other crops, mainly cassava, beans, and maize. The same observation was reported by Bashaasha et al. (1995). Intercropping is the practice of growing two or more crops together in one field (Khan et al., 2012). The main objective of intercropping is to maximize the land use, to control pests and diseases, to improve ecological protection, and to maximize crop output from available land (Malézieux et al., 2009). Intercropping systems may have negative or positive effects on crop yield. Interspecific competition for light and nutrients has been reported in various intercropping systems (Baumann et al., 2002; Hauggaard-Nielsen et al., 2001). The comparison of monoculture and intercropping of cereals and legumes revealed that intercropping is more profitable than monoculture (Zhang et al., 2007). A field experiment to assess the productivity of three sweetpotato cultivars intercropped with three okra cultivars revealed that the intercropping generally increased the height of okra plants height and the number of pods per okra plant. It was also observed that both pod and storage root yields were unaffected by intercropping (Njoku et al., 2007). Ndamage (1984) reported that the most beneficial effects were achieved with intercropping systems of sweetpotato and soybean; sweetpotato and bean; sweetpotato, bean, and maize; and sweetpotato, soybean, and maize. In intercropping system, sweetpotato cultivars with few branches were preferred, whereas in a monoculture system, cultivars with spreading vines were preferable because of their ability to suppress the growth of weeds (Wilson et al., 1989). These attributes of sweetpotato in intercropping systems are profitable and sustainable for food security of small-scale farmers.

Farmers use planting materials from their own fields or neighbors. This system may favor pest and disease epidemics. For example, the exchange of planting materials among farmers was reported to be the main cause of persistence and severity of sweetpotato viral diseases in east and central Africa (Aritua et al., 2007). In sweetpotato production, farmers rarely used purchased inputs and this had a negative effect on yields. Therefore, the combination of breeding and improvement of seed production systems and agricultural practices of sweetpotato are needed to enhance productivity.

Seasonal calendar of sweetpotato production. The price of sweetpotato varies through districts and months. In all surveyed districts, the high price was reported in November, December, and January, whereas low prices were reported in 
September, October, March, and April (Table 5). Patterns of food prices are indicators of food availability (Godfray et al., 2010). In Rwanda, sweetpotato is planted and harvested throughout the year and the peak harvesting month is September. This peak period corresponds with the low price of sweetpotato on the market. During this period, many sweetpotato fields are cleared to plant other crops. Therefore, large quantities of sweetpotato are marketed at the same time, leading to low demand and poor prices.

Unavailability of sweetpotato was reported in November, December, and January (Table 6). This period is marked by food insecurity in many rural families. The main cause of this food shortage is that farmers do not grow crops during the dry spell of May to August. Therefore, during November to January, limited crop harvests are available. Moreover, stocks of food crops harvested during September to January, and January to June, have been depleted or finished by then. The period of overproduction of sweetpotato was reported from April to August (Table 6). This period corresponds to a high level of food availability from several major crops for many rural families.

Gender and sweetpotato production. The present study showed that female farmers made greater contributions to sweetpotato production than male farmers (Table 8 ). This agreed with findings of Horenstein and Mundial (1989) who reported that sweetpotato is grown by rural households for food and cash, and women play a major role in its cultivation. Women have an important role to ensure household food security. Agriculture is the main activity of smallholders and women farmers who constitute the largest proportion of the smallholder farming system. According to FAO (2000), $96 \%$ of rural women work in field and provide three-fourths of farm labor. As a rule of thumb in rural areas, women tend to focus on food crops and men on cash crops. This ties in with the finding that crop production by women contributed more to household food security than the income from cash crops usually managed by men (Quisumbing et al., 1995). Therefore, to improve food security and to satisfy the food needs of the current growing population, it is necessary to acknowledge the importance of women in food crop production systems and the need to involve women in development of new crop cultivars and agricultural technologies (Carney, 1999).

Women participate in the market of agricultural products as suppliers and buyers. They sell different food and cash crops from their farms. However, their responsibility of managing income from agricultural products is limited (Horenstein and Mundial, 1989). This study concurred with previous findings, showing that when there is a good market for sweetpotato, income from sales are managed by men, a social dynamic that may demotivate women from sweetpotato production for the cash economy.

\section{Conclusion}

Sweetpotato is among the main food crops of many rural poor households. In
Rwanda its contribution in family food security and income generation varies from one district to another. To ensure food security for Rwanda's growing population, strategic sweetpotato production is imperative, gearing toward food security and income generation. Farmers identified the major production constraints of sweetpotato to include drought stress, shortage of improved cultivars, diseases and pests, and a shortage of planting materials. Quality traits such as high dry matter content of storage roots and early maturity were important attributes for storage root and sweetpotato cultivars, respectively. Therefore, to sustain sweetpotato production, there is a need to breed and release drought-tolerant cultivars with high dry matter and $\beta$-carotene content. Furthermore, sweetpotato breeding programs need to consider all of the documented farmers' preferred traits such as disease and pest resistance, high yield, and early maturity.

\section{Literature Cited}

Abidin, P., F. Eeuwijk, P. Stam, P. Struik, M. Malosetti, R.O.M. Mwanga, B. Odongo, M. Hermann, and E. Carey. 2005. Adaptation and stability analysis of sweetpotato varieties for low input systems in Uganda. Plant Breed. 124:491-497.

Adesina, A.A. and J. Baidu-Forson. 1995. Farmers' perceptions and adoption of new agricultural technology: Evidence from analysis in Burkina Faso and Guinea, West Africa. Agr. Econ. 13:1-9.

Aritua, V., B. Bua, E. Barg, H. Vetten, E. Adipala, and R. Gibson. 2007. Incidence of five viruses infecting sweetpotatoes in Uganda: The first evidence of sweetpotato caulimo-like virus in Africa. Plant Pathol. 56:324-331.

Ashby, J.A. and N. Lilja. 2004. Participatory research does it work? Evidence from participatory plant breeding. Crop Science Congress, Brisbane, Australia.

Atlin, G., M. Cooper, and Å. Bjørnstad. 2001. A comparison of formal and participatory breeding approaches using selection theory. Euphytica 122:463-475.

Bänziger, M. and M. Cooper. 2001. Breeding for low input conditions and consequences for participatory plant breeding examples from tropical maize and wheat. Euphytica 122:503-519.

Bashaasha, B., R. Mwanga, C. Ocitti p'Obwoya, and P. Ewell. 1995. Sweetpotato in the farming and food systems of Uganda: A farm survey report. International Potato Center (CIP), Nairobi, Kenya.

Baumann, D., L. Bastiaans, J. Goudriaan, H. Van Laar, and M. Kropff. 2002. Analysing crop yield and plant quality in an intercropping system using an eco-physiological model for interplant competition. Agr. Syst. 73:173-203.

Brown, M.E. and C.C. Funk. 2008. Food security under climate change. University of Nebraska, Lincoln, NE.

Carney, D. 1999. Approaches to sustainable livelihoods for the rural poor. Afr. Pol. Econ. 26: 171-189.

Ceccarelli, S. 2012. Plant breeding with farmers a technical manual. ICARDA, Aleppo, Syria. p. xi, 126.

Ceccarelli, S. and S. Grando. 2009. Participatory plant breeding, p. 395-414. In: Carena, M.J. (ed.). Cereals. Springer, New York, NY.

Ceccarelli, S., S. Grando, and M. Baum. 2007. Participatory plant breeding in water-limited environments. Exp. Agr. 43:411-436.
Ceccarelli, S., S. Grando, R. Tutwiler, J. Baha, A. Martini, H. Salahieh, A. Goodchild, and M. Michael. 2000. A methodological study on participatory barley breeding: Selection phase. Euphytica 111:91-104.

Ceccarelli, S., E.P. Guimarães, and E. Weltzien. 2009. Plant breeding and farmer participation. FAO, Rome, Italy.

Chassy, B., M. Egnin, Y. Gao, G. Kleter, P. Nestel, M. Newell-McGloughlin, R. Phipps, and R. Shillito. 2008. Nutritional and safety assessments of foods and feeds nutritionally improved through biotechnology. Comprehensive Reviews in Food Science and Food Safety 7:50-113.

FAO. 2000. Women and developing agriculture. Food Agriculture Organisation, Rome, Italy.

FAOSTAT. 2013. Statistics division. FAO, Rome, Italy.

Fuglie, K.O. 2007. Priorities for sweetpotato research in developing countries: Results of a survey. HortScience 42:1200-1206.

Gibson, R.W., V. Aritua, E. Byamukama, I. Mpembe, and J. Kayongo. 2004. Control strategies for sweetpotato virus disease in Africa. Virus Res. 100:115-122.

Gibson, R.W., E. Byamukama, I. Mpembe, K. James, and R.O.M. Mwanga. 2008. Working with farmer groups in Uganda to develop new sweetpotato cultivars: Decentralisation and building on traditional approaches. Euphytica 159:217-228.

Githunguri, C.M., C.C.K. Ariithi, R. Kapinga, S. Agili, Y.N. Migwa, J.K.M. Ng'ang'a, and L. Mutuku. 2006. Farmers' perceptions of plant growth and organoleptic characteristics on elite sweetpotato clones in Machakoc and semi-arid Eastern Kenya. Ruforum 2:12-19.

Godfray, H.C.J., J.R. Beddington, I.R. Crute, L. Haddad, D. Lawrence, J.F. Muir, J. Pretty, S. Robinson, S.M. Thomas, and C. Toulmin. 2010. Food security: The challenge of feeding 9 billion people. Science 327:812-818.

Hauggaard-Nielsen, H., P. Ambus, and E.S. Jensen. 2001. Interspecific competition, $\mathrm{N}$ use and interference with weeds in pea-barley intercropping. Field Crops Res. 70:101-109.

Horenstein, N.R. and B. Mundial. 1989. Women and food security in Kenya. Population and Human Resources Department, World Bank, Washington DC.

Kapinga, R. and E.E. Carey. 2003. Present status of sweetpotato breeding for Eastern and Southern Africa, p. 3-8. In: Ree, D. (ed.). Sweetpotato post harvest assessment: Experiences from East Africa, NRI, CPHP, DFID, CIP and Ministry of Agriculture Tanzania, Chatman, UK.

Kayitare, L. 2006. Rwanda food security update. News Net of World food programme, KigaliRwanda. p. 1-6.

Khan, M.A., K. Naveed, B.A. Kawsar Ali, and S. Jan. 2012. Impact of mungbean-maize intercropping on growth and yield of mungbean. Pakistan J. of Weed Sci. Res. 18:191-200.

Laurie, S. and M. Magoro. 2008. Evaluation and release of new sweetpotato varieties through farmer participatory selection. Afr. J. of Agr. Res. 3:672-676.

Lebot, V. 2009. Sweetpotato, p. 97-125. In: Bradshaw, J.E. (ed.). Root and tuber crops: Handbook of plant breeding. Springer Sciences and Business Media, New York, NY.

Lilja, N. and A. Aw-Hasaan. 2003. Benefits and costs of participatory barley breeding in Syria. The 25th international conference of IAAE, CIMMYT, Durban, South Africa.

Malézieux, E., Y. Crozat, C. Dupraz, M. Laurans, D. Makowski, H. Ozier-Lafontaine, B. Rapidel, S. De Tourdonnet, and M. Valantin-Morison. 
2009. Mixing plant species in cropping systems: Concepts, tools and models. Agron Sustain. Dev. 29:329-353.

Muyinza, H., P. Stevenson, R. Mwanga, H. Talwana, J. Murumu, and B. Odongo. 2007. The relationship between stem base and root damage by Cylas spp. on sweetpotato. Afr. Crop Sci. Soc. 8:955-957.

Ndamage, G. 1984. Sweetpotato production potential in Rwanda. Triennial Root Crops Symposium of the International Society for Tropical Root Crops, IDRC, Douala.

Ndamage, G., P. Ntawuruhunga, and J. Mulindangabo. 1992. Progrès de la recherche sur les plantes à racines et tubercules au Rwanda, 1984-1991. Institut des Sciences Agronomiques du Rwanda et Centre de Recherches pour le Developpement International, Butare.

NISR. 2010. Integrated household living conditions survey. DFID, Kigali.

NISR. 2012. The provisional results of the 4th population and housing census of Rwanda. National Institute of Statistics of Rwanda, Kigali-Rwanda.

Njeru, R., M. Bagabe, D. Nkezabahizi, D. Kayiranga, J. Kajuga, L. Butare, and J. Ndirigue. 2008. Viruses infecting sweetpotato in Rwanda: Occurrence and distribution. Ann. Appl. Biol. 153:215-221.

Njoku, S., C. Muoneke, D. Okpara, and F. Agbo. 2007. Effect of intercropping varieties of sweetpotato and okra in an ultisol of southeastern Nigeria. Afr. J. Biotechnol. 6:1650-1654.
Payne, R.W., D.A. Murray, S.A. Harding, D.B. Baird, and D.M. Soutar. 2011. An introduction to GenStat for Windows. 14th Ed. Hemel Hempstead, UK.

Quisumbing, A.R., L.R. Brown, H.S. Feldstein, L. Haddad, and C. Peña. 1995. Women: The key to food security. The International Food Security Research Institute, Washington, DC

Rees, D., Q.E.A. van Oirschot, R. Amour, E. Rwiza, R. Kapinga, and T. Carey. 2003. Cultivar variation in keeping quality of sweetpotatoes. Postharvest Biol. Technol. 28:313-325.

Rwakabuba, N. 2012. Orange fleshed sweetpotato biscuit at Urwibutso entreprise. RAB, Center for Agricultural Information and Communication (CICA), Kigali.

Shaikh, J. and L. Mahy. 2003. Assessment of the vitamin A situation in Rwanda. USAID, Kigali, Rwanda.

Song, Y. 1998. New seed in old China: Impact of CIMMYT collaborative programme on maize breeding in south-western China. Universiteit Wageningen, Landbouw, The Netherlands.

Sperling, L., J.A. Ashby, M.E. Smith, E. Weltzien, and S. Mc. Guire. 2001. A framework for analyzing participatory plant breeding approaches and results. Euphytica 122:106-119.

SPSS. 2006. PASW Statistics for Windows SPSS Inc. SPSS Inc., Chicago, IL.

Tester, M. and P. Langridge. 2010. Breeding technologies to increase crop production in a changing world. Science 327:818-822.
Tilman, D., J. Fargione, B. Wolff, C. D’Antonio, A. Dobson, R. Howarth, D. Schindler, W.H. Schlesinger, D. Simberloff, and D. Swackhamer. 2001. Forecasting agriculturally driven global environmental change. Science 292:281-284.

Tshuma, M.C. 2012. A review of the poverty and food security issues in South Africa: Is agriculture the solution? Afr. J. Agr. Res. 7:4010 4020 .

Van Jaarsveld, P.J., M. Faber, S.A. Tanumihardjo, P. Nestel, C.J. Lombard, and A.J. Spinnler Benade. 2005. $\beta$-carotene-rich orange fleshed sweetpotato improves the vitamin A status of primary school children assessed with the modified relative dose response test. Amer. J. Clin. Nutr. 81:1080-1087.

Wilson, J.E., F.S. Pole, N.E.J. Smit, and P. Taufatofua. 1989. Sweetpotato breeding. IRETA publications Apia, Western Samoa.

Witcombe, J., A. Joshi, K. Joshi, and B. Sthapit. 1996. Farmer participatory crop improvement: Varietal selection and breeding methods and their impact on biodiversity. Exp. Agr. 32:445460.

Woolfe, J.A. 1992. Sweetpotato: An untapped food resource. Cambridge University Press, New York, NY.

Zhang, L.-Z., W. Van der Werf, S.-P. Zhang, B. Li, and J. Spiertz. 2007. Growth, yield and quality of wheat and cotton in relay strip intercropping systems. Field Crops Res. 103:178-188. 